\title{
МОЖЛИВОСТІ ДЛЯ ВНУТРІШНІХ ВОДНИХ ШЛЯХІВ УКРАЇНИ АБО ПЕРСПЕКТИВИ ВПРОВАДЖЕННЯ Е-40 ДЛЯ УКРАЇНИ ШЛЯХОМ ОБ'ЄДНАННЯ ЧОРНОГО Й БАЛТІЙСЬКОГО МОРІВ
}

Транспортне законодавство є комплексним та містить норми різної галузевої належності. При цьому більшість суспільних відносин за участі транспорту регулюється масивом нормативно-правових актів. Враховуючи різноманітність і специфічність суспільних відносин у транспортній сфері, а також відсутність єдиного методу ї правового регулювання, в науці пропонується розроблення базового нормативного акту транспортної сфери - Основ транспортного законодавства або Транспортного кодексу, аргументується прийняття транспортних кодексів на автомобільному, внутрішньому водному, залізничному транспорті. Проте 3 зазначеного очевидно, що наявний масив суспільних відносин, які реалізуються в транспортній сфері значно випередили наявну нормативно-правову базу. Тобто генезис суспільних правовідносин на транспорті (залізничному, автомобільному, повітряному, водному) $є$ прогресивнішим за процес законодавчих змін. У зв'язку 3 цим підкреслюємо, що сутність суспільних відносин на транспорті має корелювати зі змістом закріплених правових норм. В цьому випадку можна розглядати кілька напрямів: Захід - Схід, де Украіна немає водних шляхів, та Південь Північ, де вони є. Хоча Захід - Схід представляє собою найбільш перспективний напрям, для України він став «неприйнятним» в силу звісних причин. Буде зайвим нагадувати, що геополітичне розташування України унікальне, завдяки йому вона, теоретично, цілком могла б брати участь у товарообігу ЄC 3 Китаєм. В рамках цієї ініціативи розбудовується наймасштабні- ший транспортно-логістичний проект XXI ст., який поєднає Китай та країни Західної Європи. Наразі превалювання зовнішніх факторів свідчить про нездатність законодавчих ініціатив відповідати викликам. В переважній більшості тотальності провалу транспортного законодавства щодо внутрішніх водних шляхів для країни має стати більш зважене прийняття чи скасування законодавчих змін.

Наразі розгляд нової інфраструктурної ініціативи не можливе без історичного екскурсу стосовно тих чи інших транспортних коридорів й водних шляхів. Деякі аспекти стосовно Шовкового шляху розглянуті у роботах таких науковців, як: I.M. Алексєєва, O.В. Акімова, А. Бугаєнко, Р. Жангожі, Х. Ліхуа, М.Р. Мамедова, Н.Н. Мінгулов, А.А. Нурсеїтов, О.А. Омельченко, M.Я. Постан, Є.I. Сафронова, Т. Чуньфен, М.А. Федоркова, Р.Х. Шарафутдинов, І.Б. Шевель, А.Г. Яковлєва. Дослідженню питань реалізації проекту «Один пояс, один шлях» та участі України присвячено роботи таких українських науковців, як: А.С. Філіпенко, З.Я. Макогін, Л.В. Власенко, С.А. Кошовий, В. Поровозник, В. Перебийніс тощо.

Метою статті $€$ аналіз та оцінка можливостей для українських внутрішніх водних шляхів, які виникають під час об'єднання Чорного й Балтійського морів водним шляхом (Південь - Північ) та можливе використання ї в транспортному коридорі Захід - Схід.

Сьогодні темпи i масштаби розбудови транспортної інфраструктури України Захід - Схід суттєво відстають у порівнянні з відповідними про- 
цесами у азійських країнах, а також сусідніх державах України - Росії, Білорусі, які, подібно до ЄC, активно розбудовують свої транспортні мережі. Наслідком такої розбудови стає посилення конкуренції у сфері надання транспортних послуг та обслуговування основних трансконтинентальних i транснаціональних вантажопотоків i, насамперед, на напрямку «Европа Азія» [1, с. 9]. Звертаючись до історичних витоків нагадаємо, що у 1877 році німецьким вченим Фердинандом фон Ріхтгофеном було запропоновано терміни "SeidenstraЯe" i "SeidenstraЯen" (“Шовковий шлях", або “Шовковий маршрут”) для назви караванної дороги, що зв'язувала Східну Азію із Середземномор'ям у давнину і в середні віки $[2$, c. 61$]$. 3 наукової точки зору Великий Шовковий шлях означає сформовану систему торгових артерій які пов'язували головні культурні регіони Євразіі та західні країни [3, с. 173]. Враховуючи стан сучасної інфраструктури країн, що складають коридор Європа - Азія, та їх географічне розташування можна впевнено обговорювати провідне місце України в цьому проекті. Анонсування в 2013 р. Головою КНР Сі Цзіньпіном ініціативи «Один пояс - один шлях» (яка складається 3 таких частин як: «Економічний пояс шовкового шляху» та «Морський шовковий шлях XXI ст.» [4, с. 140]. Перед 2014 роком Україна домовилася з ЄС, Росією та Китаєм, що саме по території України буде проходити “Шовковий маршрут". Мається на увазі залізнодорожний (сухопутний) маршрут, який пройшов би по території країн-членів ЄС, України, РФ, Китаю і далі в азіатські країни. Почалися переговори з зацікавленими сторонами та підготовка документів для підписання, а також доробка відповідної залізнизнично-дорожної інфраструктури на українській території. Сьогодні немає сенсу сперечатися через втрачені перспективи: Україна не зуміла реалізувати себе та використати шанс щодо прямої участі в проекті «шляху з ЄС в Китай». Можна посилатися на те, що прикордонні області України з ЄС навряд чи можуть похвалитися розвинутою інфраструктурою з залізничним транспортом та великими транспортними аеропор- тами, яких немає, а їх будівництво - дуже ризиковане рішення, адже для окупності вже в перші роки повинен бути величезний товарообіг. Якщо ж вирішити ці проблеми, то співпрацювати 3 Китаєм в рамках "Нового шовкового шляху" було б реальним. Уявіть Україну базою, в яку завозяться товари і сировина з Китаю, тут перетворюються на готові продукти і відправляються в Євросоюз. Однак це залишилося в нереалізованих проектах «Шовкового шляху» Європа Китай, який перехопила Білорусь, чому передували події останніх шести років в Україні. На сьогодні транспортна система України залишається не інтегрованою 3 транс'європейською транспортною системою для забезпечення єдиного перевізного процесу. Внаслідок цього Україна поступається іншим країнам на ринку пропозицій транспортних послуг. Крім цього, зберігається стала тенденція до втрати транзитних вантажопотоків на маршруті Європа Азія. Після запровадження на початку 2016 року Росією транзитного ембарго на українські товари Україна приєдналася до міжнародного проекту "Шовковий шлях" (сухопутно-морський) транспортного маршруту в обхід Росії. Невдовзі 3 порту Чорноморськ за маршрутом Україна - Грузія - Азербайджан - Казахстан - Китай був запущений перший експериментальний рейс, який включав залізничні ділянки і поромні переправи Чорного та Каспійських морів.

Морський шовковий шлях доповнює Економічний пояс та $є$ ініціативою по інтеграції Південно-східної Азї, Океанії та Північної Африки шляхом розвитку інфраструктурних проектів у морській галузі в кількох напрямах. Перший від приморських районів Китаю, через Південно-Китайське море, до Індійського океану і в Європу. Другий - від узбережжя Китаю, через Південно-Китайське море в Південно-Тихоокеанський район [5, с. 204]. Сучасна ініціатива такого шляху включає шість економічних коридорів: Економічний коридор «Новий сухопутній міст Євразіi», Китайсько-монголо-російський економічний коридор, Економічний коридор Китай - Центральна Азія - Західна Азія, Економічний коридор Китай - 
Індокитай, Китайсько-Пакистанський економічний коридор, Економічний коридор Бангладеш - Китай - Індія М'янма [6, с. 110].

Ініціатива зі створення "Шовкового шляху” була висунута, зважаючи на принцип взаємного доповнення економік, відмінності між Китаєм та сусідніми країнами, а також на наявні недоліки в інфраструктурі всіх передбачуваних учасників цього економічного проекту. Така взаємодоповнюваність забезпечує важливу основу для довгострокового ділового співробітництва Китаю з сусідніми країнами, і навіть створення Євразійського союзу не змогло вплинути на взаємодоповнюваність економічних систем Китаю та суміжних з ним країн, адже тільки спільними зусиллями зі створення "Економічного поясу Шовкового шляху" можливо повною мірою подолати нерозвиненість інфраструктури в цьому регіоні $[7$, с. 156].

Підкреслимо, що значна увага приділяється взаємозв'язку функціональних компонентів міжнародної інфраструктури [8, с. 11-12].

Ще раз наголосимо на тому, що немає сенсу сперечатися через втрачені перспективи, адже Україна не зуміла реалізувати себе та використати шанс щодо прямої участі в проекті «сухопутного шляху з $E$ в в Китай». Можна посилатися на те, що прикордонні області України з ЄС навряд чи можуть похвалитися розвинутою інфраструктурою 3 залізничним транспортом та великими транспортними аеропортами, яких немає, а їх будівництво - дуже ризиковане рішення, адже для окупності вже в перші роки повинен бути величезний товарообіг. Якщо ж вирішити ці проблеми, то співпрацювати 3 Китаєм в рамках "Нового шовкового шляху" було б реальним. Уявіть Україну базою, в яку завозяться товари і сировина з Китаю, тут перетворюються на готові продукти і відправляються в Євросоюз. Однак це залишилося в нереалізованих проектах «Шовкового шляху» Європа - Китай, який перехопила Білорусь, чому передували події останніх шести років в Україні. На сьогодні транспортна система України залишається не інтегрованою 3 транс'європейською тран- спортною системою для забезпечення єдиного перевізного процесу. Внаслідок цього Україна поступається іншим країнам на ринку пропозицій транспортних послуг. Крім цього, зберігається стала тенденція до втрати транзитних вантажопотоків на маршруті Європа - Азія. Морський проект теж провалився скоріше через неконкурентоспроможність порівняно 3 іншими варіантами доставки вантажів з Китаю до Європи. Інші маршрути виявилися більш привабливі, ніж так званий Транскаспійський коридор, оскільки на ньому велика кількість інтермодальних моментів: перевантаження із залізниці спочатку на один паром, потім на інший. Кількість контейнерних потягів на Євразійському маршруті через Казахстан, Росію та Білорусь збільшується, а Транскаспійський коридор так і залишився на стадії випробувань. Економічна неспроможність задуму визначалася й політичною складовою. Це був період, коли Росія почала обмежувати нам експорт. Тоді було важливо показати, що є альтернатива. Однак вона дорожча, і потребує вирішення двох питань: перше питання вартість, друге - регулярність.

Отже, Україна не стала провідним транспортним ланцюгом в проектах ЄC та Китаю, втративши міліарні прибутки. Однак Україна має скористатися своїми можливостями в реалізації проекту щодо водного коридору Південь Північ, а саме активно підключитися до розбудови міжнародного водного шляху (МВШ) Е-40.

Ідею проекту МВШ Е-40 для з'єднання Балтійського моря (порт Гданськ, Польща) 3 Чорним морем (порт Херсон, Україна) можна розглядати як відновлення давнього водного шляху із «Варяг в Греки» [9, с. 6].

Проект МВШ має дати країнам, розташованим по Шовковому шляху, можливість скорегувати свою економічну політику в бік більш масштабного i глибокого регіонального співробітництва, спільно сформувати структуру відкритого, толерантного, збалансованого і вигідного регіонального економічного співробітництва, а також будівництво єдиної транспортної інфраструктури від Тихого океану 
до Балтійського моря, поглиблення торговельних зв'язків з ліквідацією бар'єрів, ведення вільної торгівлі, прискорення часу доставки вантажів, збільшення між активно розвиваючим свої торговельні зв'язки Китаєм та країнами Західної Європи [10, с. 6]. Цьому сприяє, по-перше, зручне географічне розташування України, наявність розвиненої транспортної інфраструктури. По-друге, варто зазначити на наявність у багатьох судноплавних ліній прямого сервісу між головними морськими портами України - Одесою, Чорноморськом та Южним - та найбільшими портами Європи. Таким чином, Новий шовковий шлях відіграватиме важливу роль в розвитку економічного потенціалу України. За своїм географічним розташуванням територія України унікальна. Адже вона межує 3 десятьма країнами: Росією, Білоруссю, Польщею, Словаччиною, Угорщиною, Румунією, Молдовою - по сухопутному кордону, і Грузією, Туреччиною, Болгарією, Румунією - по морському. Таким чином, для зв'язку між Європою та Азією Україна з географічної точки зору $€$ найпривабливішим учасником, адже через іi територію можна здійснювати перевезення до Грузіі, а також країн Європи через Польщу та ін. [11, c. 77].

Нині міжнародна спільнота має намір приєднати до проекту Шовкового шляху що $є$ перспективним аспектом розвитку як для Китаю, так і для Украіни як у геополітичному, так і в економічному напрямку. Адже саме Україна може виступити головною зв'язуючою ланкою.

Стосовно об'єднання Балтійського й Чорного морів точаться дискусії, а шлях намагаються відродити протягом останніх шести років. Маршрут, який з'єднує Балтійське і Чорне море називається Е-40. Створена двісті років тому водна магістраль з'єднувала порти Гданська і Херсона. Сьогодні цей шлях судноплавний лише частково.

Вантажні судна пустять через Україну, Білорусь і Польщу по річках Вісла, Західний Буг, Прип'ять і Дніпро. Цей маршрут (через Дніпровсько-Бузький канал, що з'єднує басейни Прип'яті та Бугу) діяв до Другої світової війни понад сто років.
Відродження маршруту пожвавить торгівлю між Польщею, Білоруссю і Україною: одна баржа на 900 тон замінює 18 вагонів або 45 вантажівок на 20 тон.

Вигоду повинні отримати всі: по річці перевозити товари дешевше і швидше, ніж по автотрасах. Україна зможе вийти в позитивний торговельний баланс, продаючи більше, вважають експерти. Білорусь теж налаштована стати "морською державою" і вже почала будувати порт поруч з Україною.

3 економічної точки зору, ініціатива "Один пояс - Один шлях" акцентує увагу на створенні нових і модернізацію існуючих економічних коридорів - транспортних комунікацій (автомобільних доріг, залізничних шляхів, аеропортів, морських терміналів тощо), а також супутньої інфраструктури (включаючи логістичні центри, складські термінали тощо). Результатом цієї інтеграції має стати, зокрема, повне зняття бар'єрів, що заважають вільному руху економічних факторів (товарів, послуг, капіталів, робочої сили, валюти тощо) [12, с. 15].

Припустимо, що міжнародних водний шлях E-40 стане новим торговельним шляхом між портами Балтійського та Чорного морів, сприятиме залученню інвестиції в регіон та створить нові робочі місця. Проте є думка, що проект E-40 стане катастрофою для екосистеми Полісся - одного із останніх регіонів Європи, які ще перебувають у природному стані, адже будівництво та експлуатація водного шляху передбачає будівництво та реконструкцію гідротехнічних споруд, збільшення розміру фарватеру, вирівнювання русла річок, днопоглиблювальні роботи тощо. Ці роботи та експлуатація водного шляху призведе до зміни гідроморфологічних умов всього регіону Полісся, що викличе деградацію цінних територій водно-болотних угідь, які перебувають під національним та міжнародним захистом як ареал оселищ цінних видів, та низки вразливих природних територій України [9, с. 6].

Вихід найдієвіший і витратний - це взагалі не чіпати забруднені ділянки акваторії, а обійти їх, побудувавши поряд 3 річкою судноплавний канал. Благо, що є багатий зарубіжний досвід 
побудови подібних каналів. Наприклад, вся Голландія в таких штучних судноплавних каналах.

Наразі Україна розглядає свою роль у проекті «Один пояс, один шлях» насамперед як транспортно-логістичного вузла. Україна має унікальну можливість стати осередком розбудови «Одного поясу, одного шляху» у Чорноморсько-Балтійському регіоні із залученням країн Балтії, Вишеградської четвірки, Румуніі, Болгарії, Білорусі, Грузіі.

Підсумовуючи вищезазначене відмітимо, що можливим вирішенням проблеми хаотичного прийняття тих чи інших нормативно-правових актів $€$ чітке осмислене розуміння законодавця нагальної необхідності у дії прописаних норм. Тобто необхідно приймати спеціальний профільний закон під конкретні цілі. Ініціатива «Один пояс - Один шлях» потребує не лише ідеолого-практичного інтересу, а й нормативного закріплення задля майбутньої реалізації ініціатив щодо об’єднання транспортних коридорів й безперечної спільної транспортної інфраструктури й послуг. Економічну вигоду від участі в зазначених проектах Україна отримали б не тільки від торгівлі: сам факт присутності у "Новому шовковому шляху" представляє собою потужний поштовх до розвитку інфраструктури, коли в транспортну систему та інфраструктуру країн-учасників інвестуються кошти на суму в десятки мільярдів доларів.

у статті здійснюеться аналіз та надається оцінка можливостей для українських внутрішніх водних шляхів, які виникають під час об'єднання Чорного й Балтійського морів міннародним водним шляхом (МВШ E-40). B роботі вперше науково запропоновано об'єднати Чорне й Балтійське моря з позицій взаємодії транспортних коридорів «щовкового แляху» в координатах Захід - Cxid та Південь - Північ при реалізаціі проекту «Шовковий шлях». Звернута увага на проблемах України при реалізаціi проектів щзоо «Шовкового шляху». Виявлено, що втраченою перспективою України є пряма участь в проекті «сухопутного иляху з $E C$ в Китай» й акиентова- но увагу на тому, щз транспортна система України залишається не інтегрованою з транс'європейською транспортною системою для забезпечення єдиного перевізного процесу. Розкрито сутність транспортного коридору МВШ Е-40. Виявлені вигоди й можливості для України в цілому. й водних шляхів зокрема від участі як транспортно-логістичного вузла в проекті E-40. Аргументовано, що економічну вигоду від участі в зазначених проектах Україна отримали б не тільки від торгівлі: сам факт присутності у "Новому шовковому шляху" представляе собою потужний поштовх до розвитку інфраструктури, коли в транспортну систему та інфраструктуру країн-учасників інвестуються кошти на суму в десятки мільярдів доларів. Зәіиснено системний аналіз ініціативи «Один пояс - один шлях» шляхом обробки наукового матеріалу в сфері «Шовковий шлях» $i$ доведено, щзо ініціатива "Один пояс - Один шлях» потребує не лише ідеолого-практичного інтересу, а й нормативного закріплення задля майбутньої реалізації ініціатив щодо об'єднання транспортних коридорів й безперечної спільної транспортної інфраструктури й послуг. Bперше запропоновано створити закон про об'єднання Чорного й Балтійського морів та розроблено науково-теоретико-практичне підгрунтя для прийняття иього профільного закону про об'єднання Чорного й Балтійського морів.

Ключові слова: внутрішні водні шляхи, Е-40, «Один пояс, один шлях», Великий Шовковий Шлях, морський шовковий шлях XXI-го віку, транспортний коридор, транспортна інфраструктура.

Slatvinska V. OPPORTUNITIES
FOR ONLAND WATERWAYS
OF UKRAINE OR PROSPECTS
FOR THE IMPLEMENTATION
OF E-40 FOR UKRAINE BY
COMBINING
AND BALTIC SEAS

The article analyzes and assesses the opportunities for Ukrainian inland waterways that arise when the 
black and Baltic seas are united by international waterway (IIW E-40). For the first time, it was scientifically proposed to unite the Black sea and the Baltic sea from the standpoint of interaction of transport corridors of the silk road in the coordinates West-East and North-South in the implementation of the silk road project. Attention is drawn to the problems of Ukraine in the implementation of the silk road projects. It is revealed that the lost prospect of Ukraine is direct participation in the project "land route from the EU to China" and focuses on the fact that the transport system of Ukraine remains not integrated with the TRANS-European transport system to ensure a single transportation process. The essence of the transport corridor IIW E-40 is revealed. The benefits and opportunities for Ukraine in General and waterways in particular from participation as a transport and logistics hub in the E-40 project are revealed. It is argued that the economic benefit from participation in these projects Ukraine would receive not only from trade: the very fact of presence in the "New silk road" is a powerful impetus to the development of infrastructure, when the transport system and infrastructure of the participating countries are invested in the amount of tens of billions of dollars. A systematic analysis of the initiative "One Belt-One Road" by processing scientific material in the field of "Silk Road" is carried out and it is proved that the initiative "One Belt - One Road" requires not only ideological and practical interest but also regulatory consolidation for the future implementation of initiatives to unite transport corridors and indisputable common transport infrastructure and services. For the first time, it was proposed to create a law on the unification of the Black and Baltic seas and to develop a scientific, theoretical and practical basis for the adoption of this profile law on the unification of the Black and Baltic seas.

Key words: inland waterways, E-40, "One belt, one road», Great Silk Road, the XXI century Maritime Silk Road, transport corridor, transport infrastructure.

\section{Література}

1. Венгер В. Перспективи Українсько-Китайського співробітництва у промисловій сфері: інтереси Китаю та можливості Украӥни. Європейський науковий журнал Економічних та Фінансових інноващій. 2018. № 1. С. 4-13.

2. Кіктенко В.О. Семантика і прагматика концепту ініціатива "один пояс, один илях". Китаєзнавиі дослідження. 2018. № 1. C. 58-68.

3. Каспрук О.С. Міжнародно-правові аспекти проекту «ОДИН ПОЯС, ОДИН ШЛЯХ». Актуальні проблеми вітчизняної юриспрудениіï. 2017. № 5. С. 173-175.

4. Таран М. Китайська ініціатива "Один пояс - один шлях» та стратегічні виклики для США. Американська історія та політика. 2017. № 4. С. 139-151.

5. Гловащька C.M. Значення стратегічної ініціативи "Один пояс, один шлях» для України. Розвиток транспорту. 2018. № 2 (3). С. 202-211.

6. Українецьь Л.А. Ініціатива «Пояс $i$ Шлях» як основа нарощування економічної експансї̈ Китаю. Науковий вісник Ужгородського національного університету. 2019. Bun. 24. 4. 3. C. 109-113.

7. Чжан Лу Економічнии пояс Шовкового иляху: історія, розвиток, перспективи. Наукові праці МАУП. 2016. № 3 (50). C. 154-158.

8. The "One Belt, One Road" initiatives. Maritime insight. 2015. № 1. P. 10-13.

9. Міжнародний водний илях Е40 Гданськ - Херсон - джерело багатства чи генератор катастроф? / Укладачі : Г. Веремійчик, О. Гусєв. - Київ : НЕЦУ, 2018. 24 с.

10. Трофимчук А.П. Перспективи приєднання України до проекту "Один пояс один шлях». Міжнародні відносини Серія «Економічні науки». 2016. № 9. С. 1-14.

11. Постан М.Я., Федоркова М.А. Аналіз перспектив участі України у відтворенні Великого Шовкового Шляху. Розвиток методів господарювання та управління на mpancnopmi. 2017. № 3 (60). С. 73-84.

12. Лі Інін, С.В. Захарін, М.В. Волосюк. Перспективи зростання торгово-економічного співробітництва Китайської Народної Республіки та України в контексті реалізації ініціативи «Один пояс один шлях». Економіка та держава. 2018. № 5 . C. 14-16. 